\title{
Minimum Wages and their Alternatives: A Critical Assessment
}

\author{
ANDREAS KNABE \\ RONNIE SCHÖB \\ CESIFO WORKING PAPER NO. 2494 \\ CATEGORY 4: LABOUR MARKETS \\ DECEMBER 2008
An electronic version of the paper may be downloaded
- from the SSRN website: www.SSRN.com
- from the RePEc website: $\quad$ www.RePEc.org \\ - from the CESifo website: www.CESifo-group.org/wp
}




\title{
Minimum Wages and their Alternatives: A Critical Assessment
}

\begin{abstract}
Do minimum wages reduce in-work-poverty and wage inequality? Or can alternative policies do better? We evaluate theses issues for the exemplary case of Germany that suffers from high unemployment among low-skilled workers and rising wage dispersion at the bottom of the wage distribution. We analyze the impact of three different policy options, currently discussed in Germany, on employment, wage inequality, public expenditures, and incomes of poor households: 1) a statutory minimum wage, 2) a combination of minimum wages and wage subsidies as e.g. in France and the Netherlands, and 3) pure wage subsidies to low-paid workers. We find that a minimum wage of EUR 7.50 would cost 840,000 low-paid jobs and increase the fiscal burden by about EUR 4 billion per year, while poor households' income rises only by EUR 1.1 billion per year. With pure wage subsidies, the government can ensure more favorable employment and income effects. Combining a minimum wage with a wage subsidy turns out to be extremely costly and inferior to wage subsidies in all respects.
\end{abstract}

JEL Code: H2, I3, J3.

Keywords: statutory minimum wage, working poor, welfare system, wage subsidy.

Andreas Knabe

School of Business \& Economics

Free University Berlin

Boltzmannstrasse 20

14195 Berlin

Germany

andreas.knabe@fu-berlin.de
Ronnie Schöb

School of Business \& Economics

Free University Berlin

Boltzmannstrasse 20

14195 Berlin

Germany

ronnie.schoeb@fu-berlin.de

November 2008 


\section{Introduction}

Minimum wages regulate the low-skilled labor market in many European countries. One of the few exceptions is Germany. For a long time, neither politicians nor labor unions in Germany saw a need to introduce statutory minimum wages. Wages were set by employer federations and labor unions through collective bargaining, and these wage-setting institutions achieved to keep the wage structure relatively stable until the mid-1990s (Prasad 2004). At the same time, demand for low-skilled workers fell in almost all industrialized countries (Acemoglu 2002). Since the rigid German wage structure prevented the wages of the lowskilled to adjust accordingly, unemployment rates of these groups increased.

Since the mid-1990s, various forces have contributed to soften the rigid German wage structure. De-unionisation and fierce low-wage competition from Central and Eastern European countries exerted considerable pressure on the low-wage segment of the wage structure. Between 2003 and 2005, the German government enacted drastic labor market reforms to increase flexibility especially at the bottom end (the so-called Hartz-reforms and the Agenda 2010, see Sinn et al. (2006b) for an overview). The reforms comprised a restructuring of the German Federal Employment Office, liberalizing the market for temporary work agencies, and subsidizing self-employment and low-paid, part-time jobs (socalled "Minijobs"). The most important policy change, however, was the complete restructuring of the German welfare system with the aim to strengthen its "welfare-to-work"approach. Benefit levels were reduced, work requirements were toughened, and new activating measures (for example, workfare jobs) were introduced. At the same time, in-workbenefits were extended, so that welfare recipients who took up a low-paid job could keep more of their earnings. Taken together, these policies intended to make low-paid work more attractive to welfare recipients and revitalize the low-skill labor market in Germany.

While it is still too early for a definitive evaluation, there are signs that the wage restraint of the last decade, combined with the recent reforms, have affected the German labor market in the intended way. Within three years, the German unemployment rate fell from 11.6 percent to 7.6 percent and for the first time, also the number of the long-term unemployed has fallen substantially. Despite this success, reforming the labor market and reintegrating the low-skilled has come at a cost. Since the mid-1990s, wage inequality has started to rise at the 
bottom of the distribution (Dustmann et al., 2008). To prevent “in-work-poverty”, the reforms prepared the government to step in and pay supplementary benefits to low-income earners.

While the public was willing to accept rising inequalities and high levels of public expenditures as a prerequisite for economic recovery at a time of high unemployment, now that the recovery is there, this willingness diminishes. The Social Democrats (who govern in a grand coalition with the Christian Democrats and were responsible for the Agenda 2010), the Left Party and the labor unions use this window of opportunity and propose a statutory minimum wage. The proponents of minimum wages bring forward two main benefits of minimum wages. First, minimum wages can stop the downward pressure on wages for the low-skilled and possibly reverse the trend of rising wage inequality. Second, if low-skilled workers earn higher wages on the labor market, the government has to spend less on supplementary welfare benefits. By introducing minimum wages, one can apparently kill two birds with one stone.

Unfortunately, minimum wages would also kill a third bird one would like to keep alive: employment opportunities for low-skilled workers. To avoid this, Germany’s neighbors often combine minimum wages with some type of wage subsidy that compensates firms for the burden the minimum wage imposes on them. In France, for instance, the government subsidizes employers' social security contributions up to the 1.6-fold of the minimum wage (see Kramarz and Philippon (2001) and Laroque and Salanié (2002) for details). A similar program is in place in the Netherlands. The Dutch SPAK is a permanent reduction in employer's social security contributions for low paid workers up to 115 percent of the minimum wage (Mühlau and Salverda 2000 and de Mooij 2006). A similar scheme has been implemented in Belgium (Marx 2001).

Rather than using the subsidy as a complementary policy only, one may be inclined to consider it as a sensible policy without introducing a minimum wage in the first place. Depending on whether the incidence of the subsidy falls on employers or employees, a wage subsidy could increase employment and/or the incomes of low-skilled workers without endangering their employment opportunities.

In this paper, we want to evaluate which of these three policy options may suit Germany best to simultaneously secure employment opportunities and sufficient incomes in the lowwage sector. After describing the current system of the German low-wage labor market in Section 2, we examine in Section 3 how the introduction of a statutory minimum wage would 
affect employment, wage inequality, public expenditures, and aggregate income in the German low-wage sector by using data from the German Socio-Economic Panel (GSOEP). ${ }^{1}$ We then use the same data to simulate the effects of combining minimum wages and wage subsidies (Section 4). In a last step, we analyze whether pure wage subsidies can be advantageous compared to pure minimum wages or a combination of both instruments (Section 5). Even though we use German data for our simulations, the policy analysis is sufficiently general to allow transferring our findings to other countries. This will be discussed in the concluding Section 6.

\section{Germany's low wage sector}

Until the mid-1990s, the German labor market was characterized by a rigid wage structure. While the pressures of globalization and technological progress led to a widening of skillspecific wage structures in most industrialized countries, wage inequality did not increase in Germany. Keeping the wage structure stable despite downward pressures on the demand for low-skilled labor led to rising unemployment rates among the least skilled. While the unemployment rates of college graduates stayed at relatively low levels over the last 20 years, the unemployment rates of unskilled workers rose from 5.3 percent in 1976 to 21.7 percent in 2005 and 19.9 percent in 2006. It might not be surprising that the unemployment rate of the low-skilled exceeds the unemployment rate of better skilled workers but Germany's troubles to reintegrate its low-skilled workers are far worse than in other industrialized countries.

Figure 1: Low-skilled unemployment in the OECD (2006)

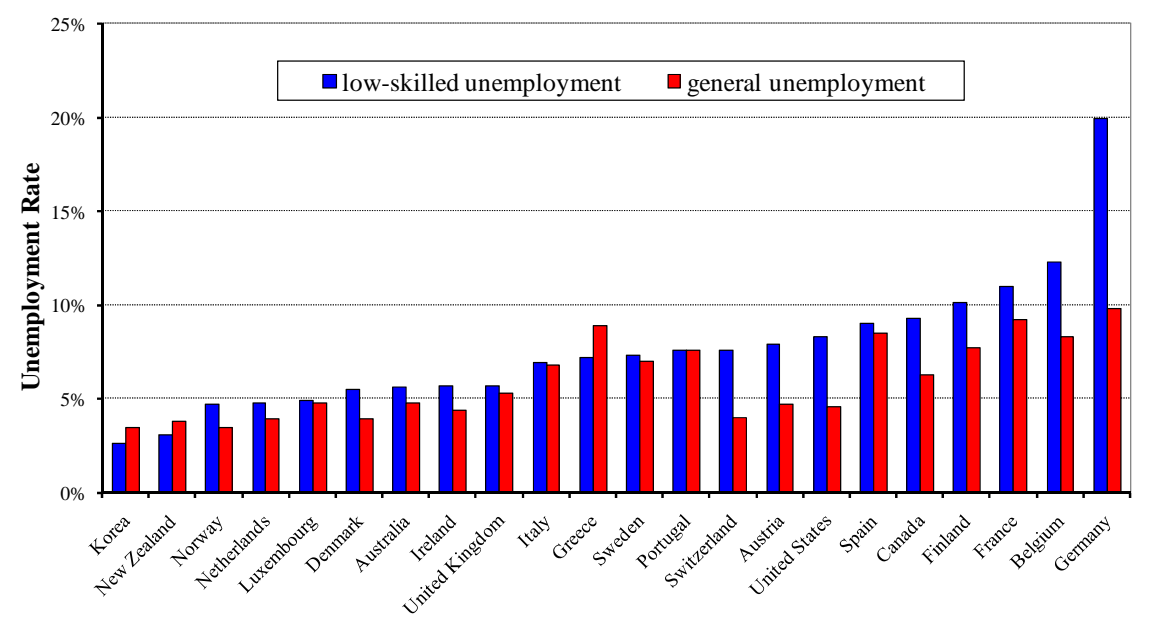

Source: OECD (2008).

\footnotetext{
${ }^{1}$ For a detailed description of the GSOEP, see Wagner et al. (2007).
} 
Note: The total unemployment rate refers to the standardized unemployment rates. Low-skilled persons are considered to have completed less than an upper secondary education.

Figure 1 compares the unemployment rates of low-skilled persons in 23 OECD-countries with the general unemployment rate in the year 2006. Germany has the highest low-skilled unemployment rate among all these countries, both in absolute terms and relative to the general unemployment rate.

Another consequence of Germany's labor market rigidities has been a large degree of hysteresis of long-term unemployment. Figure 2 shows how short-term and long-term unemployment respond to business cycle movements (where for expositional reasons, we inverted the scale for the growth rates). In the left diagram, we plot the number of short-term unemployed against annual growth rates. The short-term unemployed have qualifications and skills that are demanded on the market, and their employment prospects react promptly to changes in growth rates. This has also been true in the latest upswing. Between October 2005 and October 2008, the number of short-term unemployed has fallen by almost 50 percent. The picture looks entirely different for the long-term unemployed (right diagram in Figure 2). Long-term unemployment had been continuously increasing and appeared to be disconnected from the business cycle until 2005. At best, economic upswings in the last fifteen years had helped to decelerate the rise of long-term unemployment.

Figure 2: Short- and long-term unemployment over the business cycle

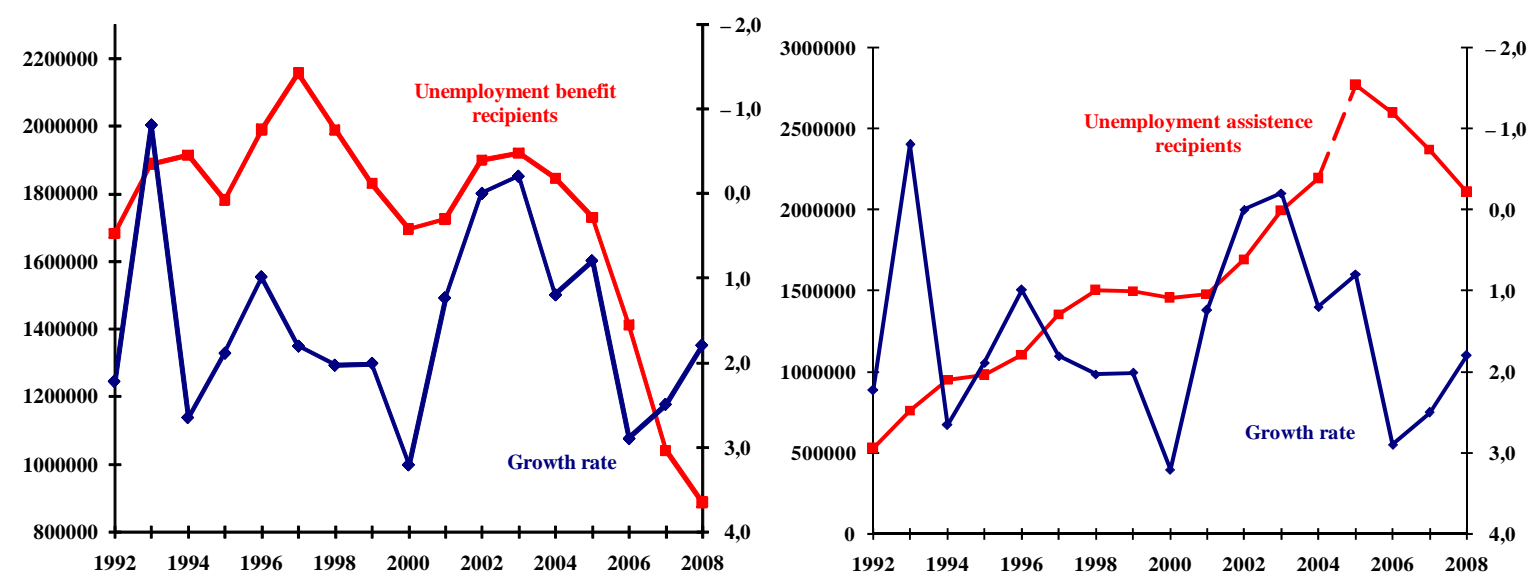

Sources: Bundesagentur für Arbeit; Destatis

In the last couple of years, however, it seems like hysteresis has finally been overcome. For the first time, an economic upswing has resulted in a fall in the number of long-term 
unemployed. From January 2007 to October 2008, the number of long-term unemployed has fallen by $24.6 \%$. A prerequisite of this development was a loosening of the rigid German wage structure. Since the mid-1990s, the wage structure has become more dispersed at the bottom end (Gernandt and Pfeiffer 2007, Dustmann et al. 2008). Various explanations for this development can be brought forward. The accession of Central and Eastern European countries brought fast-growing, low-cost economies into the EU common market and created enormous pressures for the German labor market. At the same time, labor unions have lost a lot of their bargaining power. While in 1980, about one in three employees were union members, by 2006 this was true of just one in six employees in West Germany (Schnabel and Wagner 2008). Dustmann et al. (2008) find that de-unionisation can account for $28 \%$ of the rise in inequality at the lower end of the wage distribution between 1995 and 2004, while the other 72 percent are due to changes in labor force composition and relative labor supply shocks.

The most important contribution to the recent labor market success, however, was that the German government started to give highest priority to fighting unemployment. In 2002, the commission "Modern Labor Market Services", chaired by Peter Hartz, at the time Chief Personnel Officer at Volkswagen, and consisting mainly of business executives, union officials and politicians, was established. This led to the so-called Hartz-reforms (later referred to as the Agenda 2010). The first policy package, Hartz I (2003), aimed at liberalizing the labor market and promoting new forms of employment. The regulations of temporary work agencies were liberalized, the government started its own temporary work agencies to quickly get the unemployed back into employment, training vouchers were introduced to bring more competition into the continuing education sector and to improve its performance, and employer social security contributions for elderly workers were reduced. The second package, Hartz II (2003), turned the hierarchically organized local employment offices into customer-oriented "Job-Centers". The government extended the opportunities to work in subsidized "Mini-Jobs", so that employees in jobs with maximum earnings of EUR 400 per month are exempted from taxes and social security contributions. Unemployed persons who start their own business and do not exceed a certain earnings limit are subsidized for three years. The third package, Hartz III (2004), introduced some minor changes, such as merging various job creation schemes and renaming the federal employment office. 
The key reforms of the labor market has been Hartz IV (2005). The main aim of this reform was to activate the long-term unemployed by enforcing the principle of "rights and duties". Two formerly separate branches of the welfare system that provides means-tested benefits for long-term unemployed (Unemployment Assistance and Social Assistance) were merged into a single scheme (Unemployment Benefits II - UB II) which is now responsible for all able-to-work and needy unemployed. On average, benefit levels were significantly reduced. Now, the level of UB II depends on the "needs" of the household that are defined by the socio-cultural level of subsistence and comprises "basic needs" (Regelbedarf) and "supplementary needs" (Mehrbedarfe). Basic needs consist of the needs for food, clothes, electricity, personal hygiene, household contents, and other personal needs of daily life and also include the participation in the cultural and social life on a limited scale. This is covered by a fixed basic income support (Eckregelleistung) of currently EUR 351 per month (2008). The various supplementary needs depend on individual circumstances (e.g. for expectant mothers or single parents). Relatives who are unable to work living together with a UB II recipient receive welfare benefits (Sozialgeld). Accommodation and heating costs are completely covered as far as they are justifiable. In practice, justifiable means 45 square meters for a household of one person as well as 15 square meters for each additional member of the household. Table 1 exemplifies the calculation of the average needs for different household types.

Table 1: Average needs according to household types

$\begin{array}{cccc}\text { Basic support } & \begin{array}{c}\text { Supplementary } \\ \text { needs in } \\ \text { in EUR/month }\end{array} & \begin{array}{c}\text { Housing and } \\ \text { heating cost } \\ \text { in EUR/month }\end{array} & \begin{array}{c}\text { Total UB II } \\ \text { in EUR/month }\end{array}\end{array}$

\begin{tabular}{c|cccc}
\hline Single person & 351 & --- & 334 & 685 \\
\hline $\begin{array}{c}\text { Single parent with one child } \\
\text { under 7 }\end{array}$ & 562 & 126 & 441 & 1.129 \\
$\begin{array}{c}\text { Couple, no children } \\
\text { Couple, one child under 14 } \\
\text { Couple, two children (one } \\
\text { under 14) }\end{array} \quad 632$ & 843 & --- & 441 & 1.073 \\
\hline
\end{tabular}

Source: $3^{\text {rd }}$ German Government Report on Poverty and Wealth, Draft May 19, 2008; corrected for the new basic support figures.

At the same time, in-work-benefits were extended. According to the regulations of the German Social Code, a UB II recipient who takes up work is allowed to keep the first EUR 100 of his monthly gross wage income without facing any cut in his transfer payments. From 
the following EUR 700, he is allowed to keep $20 \%$, i.e. the transfer reduction rate within this income range is $80 \%$. The transfer reduction rate increases to $90 \%$ for gross wages above EUR 800 and EUR 1,200 (resp. EUR 1,500 if there are children in the household). Any wage income above this level is deducted at 100 per cent from UB II until the public transfer is reduced to zero. Figure 3 shows how the net income of a single person and a household with two adults and two children changes with rising gross wage income.

The dashed vertical lines indicate the gross incomes at which the respective households leaves the public transfer system. This zero-transfer-line is at a gross wage of EUR 1,285 for a single person and at EUR 2,320 for a four-person household. As Figure 3 indicates, the incentive to take up employment is very small, in particular for full-time employment with incomes above EUR 800, where the transfer-reduction rate is at least $90 \%$. In the range from EUR 1,500 to EUR 2,320, additional gross labor income does not lead to any increase in a household's net income. For comparison: the average full-time wage income in 2007 was EUR 3,015 (see Statistisches Bundesamt 2008, p. 538).

Figure 4: Household net income of potential UB II recipients

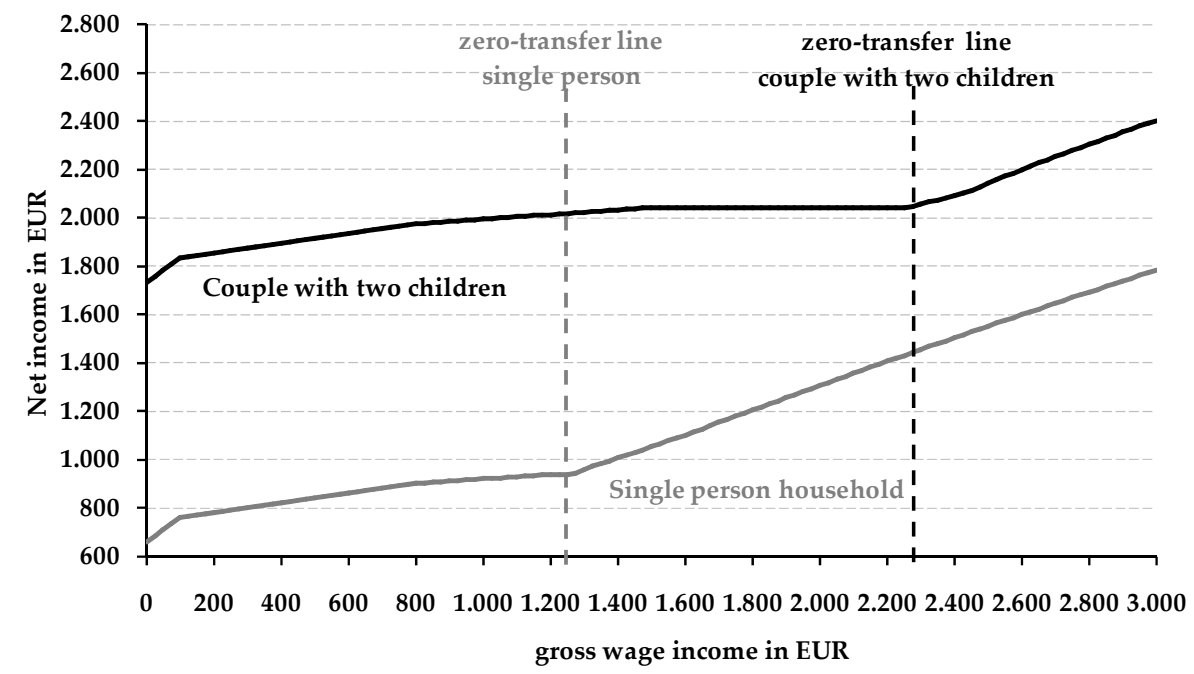

Source: Own calculations.

Legend: The gross wage is exclusive of employers' social security contributions. The zero-transfer line indicates the gross wage above which no Unemployment Benefits II are paid. The net incomes resulting from a gross income left of the zero-transfer line are calculated by taking into account the transfer reduction rates as described in the main text. To the right of the zero-transfer line, the net income is calculated by deducting the employees' social contribution payments and the income tax. 
Improved in-work-benefits are meant to "make work pay" for those willing to work. For the unwilling, the reform toughened potential sanctions if an unemployed persons does not actively try to return to employment. Jobseekers are obliged to accept any suitable job offer. The definition of suitable work was broadened, so that sub-union wages must now be accepted. A person's availability for work can additionally be tested by training or workfare measures in the public sector.

Although it is still too early to draw definitive conclusions, the recent fall in unemployment suggests that the wage restraint of the last decade in addition to the recent labor market reforms were helpful in creating more jobs and reintegrating formerly marginalized groups into the labor market (Brenke and Zimmermann 2008).

According to the Statistik der Bundesagentur für Arbeit (2008), in March 2008 a total of 1.3 million UB II recipients (about $25 \%$ of all UB II recipients) had a wage income in addition to UB II, which is a plus of more than 400,000 compared to three years before. However, the tax-transfer-system creates strong incentives to work only part-time.

Figure 4: Additional wage incomes of UB II recipients

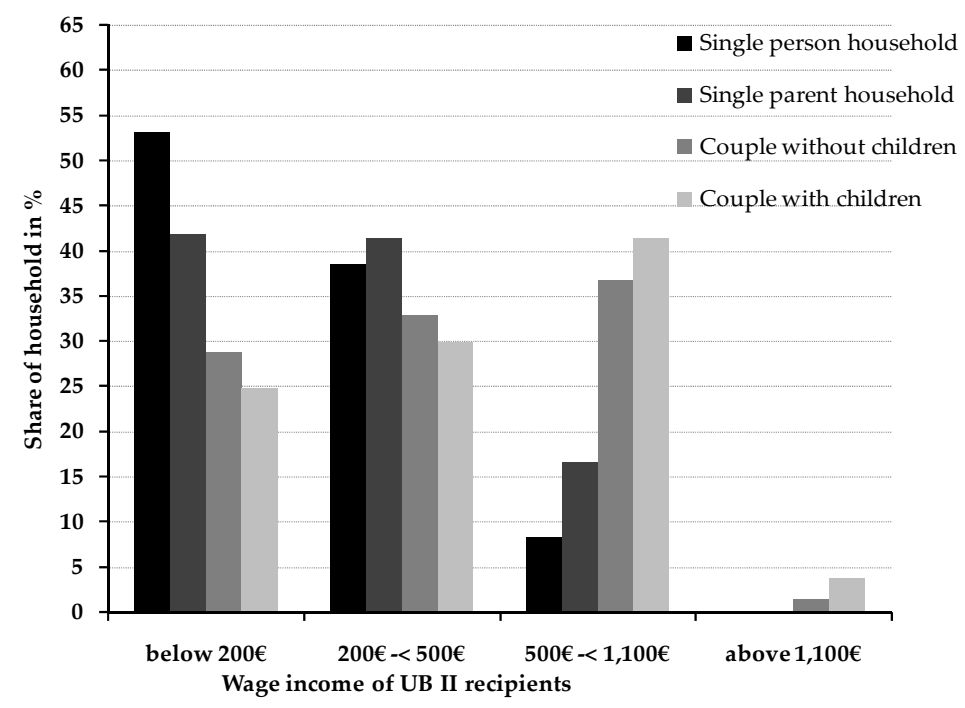

Source: Statistik der Bundesagentur für Arbeit (2008) and own calculations.

Legend: The values for single person households and for couples without children were taken directly from the Statistik der Bundesagentur für Arbeit (2008). For couples with children and single parents, the percentages are relative to the numbers of needy households in January 2007.

As Figure 4 illustrates, almost $92 \%$ of all single UB II recipients and $83 \%$ of single parents who receive UB II and work earn less than EUR 500. Apparently, the current system creates strong incentives to take up only part-time work as long as one is eligible to UB II. A more 
differentiated picture emerges only for larger households in need. Around $45 \%$ of couples with children have a gross income of more than EUR 500, i.e. most of them face an implicit marginal tax of $90 \%$ and more. This indicates that a large group of transfer recipients is willing to work in spite of high transfer reduction rates - even in ranges where the implicit marginal income tax can be as large as $100 \% .^{2}$

\section{The German minimum wage debate}

The downside of this success is rising wage inequality. Gernandt and Pfeiffer (2007) show that wage inequality has risen since 1994 (while the wage distribution stayed constant in the preceding ten years), and that, in West Germany, wage inequality primarily occurred in the lower part of the wage distribution. Acemoglu (2003) and Dustmann et al. (2008) find that wage inequality had already risen in the 1980s, but only at the top of the wage distribution. Wage inequality at the lower end has started to rise in the 1990s only.

Rising wage inequality was the bitter pill the German economy needed to swallow when unemployment was high. Since unemployment rates have started to fall in the latest economic upswing, however, it has become more difficult to convince wage setters that wages have to stay low. Rising employment figures have not only led to higher wage demands by unions, but also to the demand for a statutory minimum wage, with the main objective of avoiding inwork poverty. In the view of the minimum wage proponents, a person who works in a fulltime job should earn enough to secure a subsistence-level income without having to rely on supplementary welfare benefits.

Another argument brought forward in favor of minimum wages is that raising wages in the low-wage sector would alleviate the public budget. The recent fall in long-term unemployment was not accompanied by a similar fall in the number of UB II recipients. While the number of unemployed UB II recipients has fallen by $24.4 \%$, the total number of UB recipients only fell by $9 \%$ from January 2007 to October 2008. This is due to the fact that a rising number of workers in the low-skilled sector are eligible to supplementary transfers. As the labor market situation has improved, more and more politicians have started to complain about this development - although it was intended by the Hartz-reforms and may be

\footnotetext{
2 This may be explained by the fact that many people report a very low life satisfaction when unemployed - even when one controls for income losses. For Germany, Knabe and Rätzel (2007) find out that for a male employee the additional psychological loss is as large as the former net income and therefore higher than the actual loss of income. For female employees, the additional loss is about 60 per cent of the former income.
} 
considered as one of their great successes. It should not be the case, the argument goes, that the government pays part of the wage bill in the low wage segment of the labor market. A minimum wage should be introduced to shift the burden away from the government towards the firms. This argument is brought forward, for example, by the German Federal Ministry of Labor and Social Affairs. It argues that, in August 2007, more than 1.2 million low-wage workers had to receive in-work benefits through the welfare system to secure their subsistence level. This costs the government about EUR 1.5 billion per year (cf. Bundesministerium für Arbeit und Soziales 2008b). Even though it was the original intention of its labor market reforms to subsidize employment through in-work-benefits instead of subsidizing unemployment through welfare benefits, the Federal Ministry of Labor and Social Affairs now calls this an "erroneous trend" that can only be overcome by minimum wages that shift part of the cost of the welfare system to firms.

Most of its proponents campaign for a minimum wage of EUR 7.50 per hour. ${ }^{3}$ Such a statutory minimum wage is comparable to the levels observed in the UK and France (see Figure 5), to which the supporters of a minimum wage frequently refer to.

Figure 5: Minimum wages in Europe in July 2008 and the German minimum wage proposal

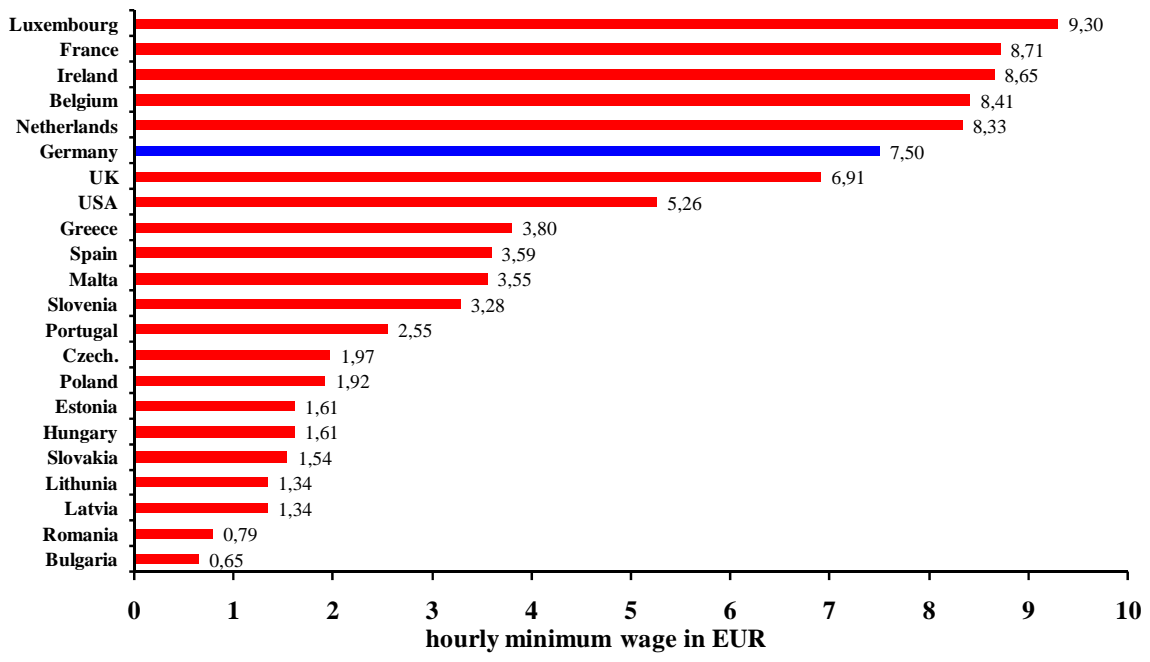

Sources: Hans-Böckler-Stiftung (2008).

\footnotetext{
3 Information about the campaign activities of minimum wage supporters can be found on the trade union federation's website: www.mindestlohn.de.
} 
Figure 6: Kaitz index (2007)

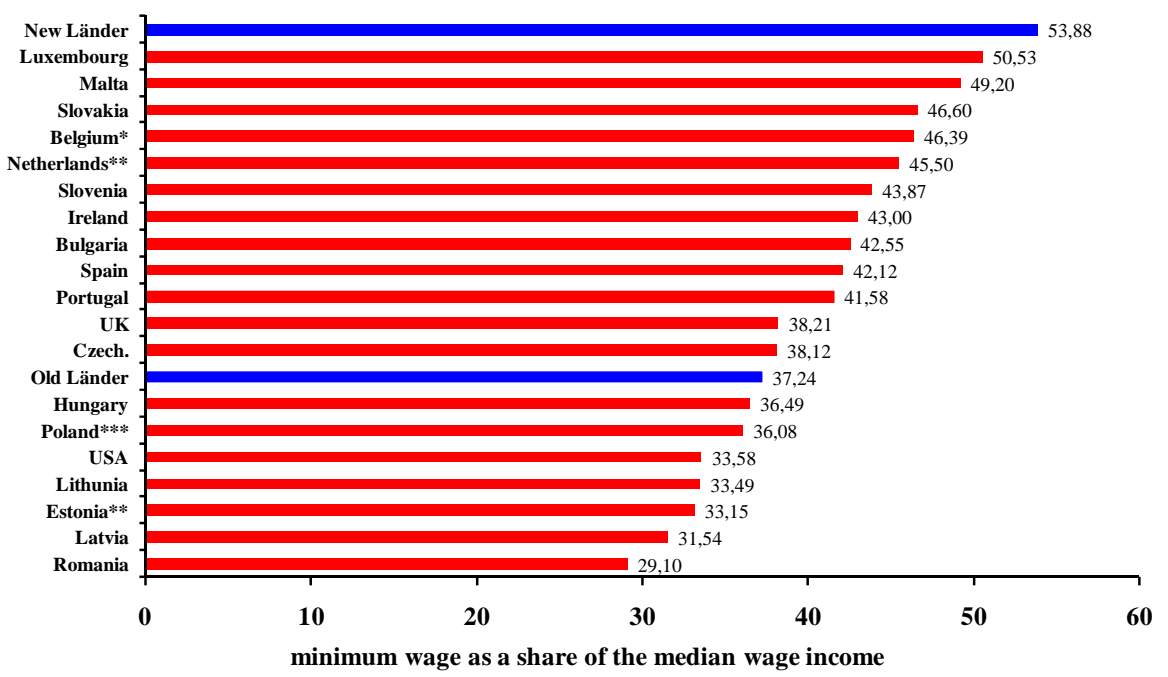

Sources: Eurostat (2008), Statistisches Jahrbuch (2008, p. 534)

Legend: The Kaitz index indicates the percentage of the monthly minimum wage in the monthly wage (annual average) paid in industry and the services sector. The data for countries marked * refer to the year 2002, for countries marked $* *$ to 2005 , for countries marked $* * *$ to 2006 , all others to 2007.

The absolute value of an hourly minimum wage provides only limited information. To assess the minimum wage, it is more important to look at how it would fit into the existing wage distribution of a particular country. Here, the Kaitz index, which relates the minimum to the median wage, provides some insights. As Figure 6 shows, the Kaitz index for European countries varies between 29 \% in Romania and $51 \%$ in Luxembourg. The proposed statutory minimum wage for Germany would yield an intermediate Kaitz index for western Germany (with $37 \%$ ), but would put eastern Germany by far on top of the ranking. With a Kaitz index of $54 \%$, eastern Germany would be ahead of Ireland by more than 5 percentage points.

To see the likely consequences of a statutory minimum wage introduced in the current German welfare system, we analyze a statutory minimum wage of EUR 7.50 per hour with respect to employment, incomes of the affected households, and the public budget. To estimate the effects, we use the distribution of gross hourly wages among different types of employees derived from the German Socio-Economic Panel (GSOEP) wave 2006 and extrapolate wages to the beginning of 2010 based on realized growth rates for 2006 and 2007 as well as expected growth rates for 2008 and 2009. ${ }^{4}$ According to these figures, $12.8 \%$ of the total workforce would be affected by an hourly minimum wage but with huge regional

\footnotetext{
${ }^{4}$ For details, see Knabe and Schöb (2008).
} 
differences. While the respective figure for West Germany is $11.7 \%$, the figure for the East is substantially higher with $18.5 \%$.

Table 2: Employment and income effects of a EUR 7.50 minimum wage

\begin{tabular}{|c|c|c|c|c|c|}
\hline & & $\begin{array}{c}\text { Share of } \\
\text { employees } \\
\text { affected }\end{array}$ & $\begin{array}{c}\text { Employment } \\
\text { losses } \\
\text { absolute }\end{array}$ & $\begin{array}{c}\text { Employment } \\
\text { losses } \\
\text { in percent }\end{array}$ & $\begin{array}{c}\text { Additional } \\
\text { income in } \\
\text { mill. Euro p.a. }\end{array}$ \\
\hline \multirow{3}{*}{ All employees } & East & $18.5 \%$ & 206,691 & 3.8 & --- \\
\hline & West & $11.7 \%$ & 635,341 & 2.3 & --- \\
\hline & Germany & $12.8 \%$ & 842,033 & 2.6 & 1,156 \\
\hline \multicolumn{6}{|l|}{ of which } \\
\hline \multirow{3}{*}{ Full-time employees } & East & $9.9 \%$ & 46,575 & 1.1 & --- \\
\hline & West & $3.5 \%$ & 109,341 & 0.6 & --- \\
\hline & Germany & $4.6 \%$ & 155,915 & 0.7 & 817 \\
\hline \multicolumn{6}{|l|}{ of which } \\
\hline \multirow{3}{*}{$\begin{array}{l}\text { Full-time employees with } \\
\text { suppl. UB II }\end{array}$} & East & $32.2 \%$ & 5,635 & 3.9 & --- \\
\hline & West & $24.6 \%$ & 9,109 & 3.9 & --- \\
\hline & Germany & $27.5 \%$ & 14,744 & 3.9 & 1 \\
\hline \multirow{3}{*}{ Part-time employees } & East & $19.3 \%$ & 16,690 & 2.3 & --- \\
\hline & West & $4.8 \%$ & 19,447 & 0.5 & --- \\
\hline & Germany & $7.1 \%$ & 36,137 & 0.8 & 132 \\
\hline \multicolumn{6}{|l|}{ of which } \\
\hline \multirow{3}{*}{$\begin{array}{l}\text { Part-time employees with } \\
\text { suppl. UB II }\end{array}$} & East & $66.5 \%$ & 5,154 & 8.2 & --- \\
\hline & West & $24.7 \%$ & 4,289 & 3.0 & --- \\
\hline & Germany & $37.3 \%$ & 9,443 & 4.5 & -5 \\
\hline \multirow{3}{*}{ Minijobs } & East & $84.5 \%$ & 110,347 & 27.1 & --- \\
\hline & West & $56.3 \%$ & 441,147 & 12.5 & --- \\
\hline & Germany & $59.2 \%$ & 551,494 & 14.0 & 142 \\
\hline \multicolumn{6}{|l|}{ of which } \\
\hline \multirow{3}{*}{$\begin{array}{l}\text { Minijobs with } \\
\text { supplementary UB II }\end{array}$} & East & $100.0 \%$ & 73,227 & 34.2 & --- \\
\hline & West & $80.0 \%$ & 71,793 & 17.0 & --- \\
\hline & Germany & $86.7 \%$ & 145,021 & 22.8 & -69 \\
\hline \multirow{3}{*}{ Pensioners } & East & $46.6 \%$ & 2,172 & 8.9 & --- \\
\hline & West & $45.5 \%$ & 33,444 & 8.1 & --- \\
\hline & Germany & $45.6 \%$ & 35,616 & 8.1 & 18 \\
\hline \multirow{3}{*}{ Students } & East & $78.7 \%$ & 30,908 & 25.1 & --- \\
\hline & West & $41.4 \%$ & 31,962 & 7.3 & --- \\
\hline & Germany & $49.6 \%$ & 62,870 & 11.2 & 47 \\
\hline
\end{tabular}

Source: own calculations. 
As Table 2 reports, $4.6 \%$ of full-time employees are affected. This fraction is larger than in the UK (2.0\%) and the Netherlands (2.2\%), but it is much lower than the fraction of French full-time employees who are paid just the statutory minimum wage $(9.0 \%) .{ }^{5}$ The share of full-time employees who have to rely on supplementary UB II - these are the main addressees of policies to fight in-work poverty - is substantially higher. More than every fourth UB II recipient who works full-time would be affected by the statutory minimum wage. The respective fraction of UB II recipients working part-time is $37.3 \%$, and of those holding a minijob, it is $86.7 \%$.

The employment effects are calculated by following the approach of Ragnitz and Thum (2007) who assume an iso-elastic labor demand elasticity of -0.75 for each wage bracket. ${ }^{6} \mathrm{~A}$ statutory minimum wage would lead to a total loss of more than 840,000 jobs (see Table 2, column 2), which corresponds to $2.6 \%$ of the workforce. Almost one fourth of the job losses would occur in eastern Germany. This would imply a reduction of the East German work force by $3.8 \%$. For the main target group of a minimum wage - full-time workers - the employment effects are much smaller. Expected job losses are about 156,000 full-time workers, i.e. $0.7 \%$ of all full-time employees. By contrast, about $77 \%$ of the job losses hit employees with a minijob, pensioners, and students. Concerning those in need, we find that about 14,000 UB II recipients who work full-time would lose their job, while about 145.000 (23\%) of the UB II recipients with a minijob would lose their supplementary wage income.

Can the minimum wage at least make low-paid workers independent of supplementary public transfers? This is one of the core objectives of the minimum wage proponents. To answer this question, we first look at a representative single-person employee who currently works full-time (160 hours per month) for an hourly gross wage of EUR 5.00.

- If the employee is entitled to supplementary UB II, the basic income when unemployed is EUR 685 per month (see Table 1). When she earns an additional labor income of EUR

\footnotetext{
${ }^{5}$ Figures for the UK and France are for 2007 and for the Netherlands for 2005 (Eurostat 2008).

${ }^{6}$ Of course, these calculations have to be interpreted with caution. Such a simulation exercise abstracts from any complementarity and substitutability relationship of the different types of work. For the purpose of our analysis, this may be justified for two reasons. First, we know very little about how output reactions affect the respective labor demand elasticity. If we assume a single output good, as Müller and Steiner (2008) do, the output reaction plays a very minor role since the factor income share of those being affected by the minimum wage is rather small. If, by contrast, we assume that workers in each wage bracket produce a separate good, we need to know the output substitution elasticities. Looking at non-marginal changes in the lower income distribution thus would make any assumption about substitution elasticities - even if based on empirical estimates - highly speculative. Second, we also know very little about the incidence of a statutory wage rise. If better paid workers face relatively flexible wages, most of the substitution effect might be evaporated by wage reactions.
} 
800, she is allowed to keep EUR 240 of her gross wage income so that her total net income would be EUR 925. If her gross hourly wage rises to EUR 7.50, she would still be entitled to supplementary UB II. Since in the income range from EUR 800 to EUR 1,200 the transfer reduction rate is $90 \%$, the monthly net income would merely rise by EUR 40 to EUR 965: a $50 \%$ increase in the gross wage results in a mere $4.3 \%$ rise in the net income.

- If the employee is not entitled to UB II, the monthly net income would rise from EUR 644 to EUR 905, i.e. by $40.5 \%$.

- As we have seen above, the minimum wage causes job losses. If an employee who receives supplementary UB II became unemployed, she would lose the EUR 240 she was allowed to keep from her gross wage income. Her monthly income would drop to EUR 685 (a $26 \%$ reduction).

- If an employee who is not entitled to UB II became unemployed after introducing the statutory minimum wage, her net income would fall from EUR 644 by $40 \%$ to EUR 386 because she would receive UB I for the first twelve months. After this, she would not be entitled to any public transfers anymore.

Figure 7 shows how these income changes affect the relative income position of the representative employee, and shows in how far a minimum wage changes the household income relative to the income threshold below which one considers a household to be 'in risk of poverty‘. According to the EU, this income threshold is at a net income of $60 \%$ of the median net income. In Germany, this would be EUR 781 per month for a single person and between EUR 1,640.10 and EUR 1,952.50 per month for a family of four, depending on the children's age. Concerning the aim to fight in-work-poverty with a statutory minimum wage, Figure 7 shows that a minimum wage of EUR 7.50 would not lift anyone above the risk-ofpoverty threshold. A full-time employee who works for EUR 5.00 per hour and receives supplementary UB II already earns a net income equal to $71 \%$ of the mean income. The minimum wage would lift his net income to $74 \%$ of the mean income. If the same employee loses his job, however, he would fall below the "risk of poverty" threshold to a mere $53 \%$ of the median income.

According to the $3^{\text {rd }}$ German government report on poverty and wealth, issued in 2008 and referring to data from 2005 (Bundesministerium für Arbeit und Soziales 2008a), only six percent of employees fall below the "risk-of-poverty" threshold, but 43 percent of the 
unemployed do so. A statutory minimum wage thus runs the risk to worsen rather than improve Germany's poverty rate: in so far as the statutory minimum wage threatens low-paid jobs, it threatens to throw low-income workers, who are above the risk-of-poverty threshold as long as they are employed, below this threshold.

Figure 8: Net incomes and the risk of poverty

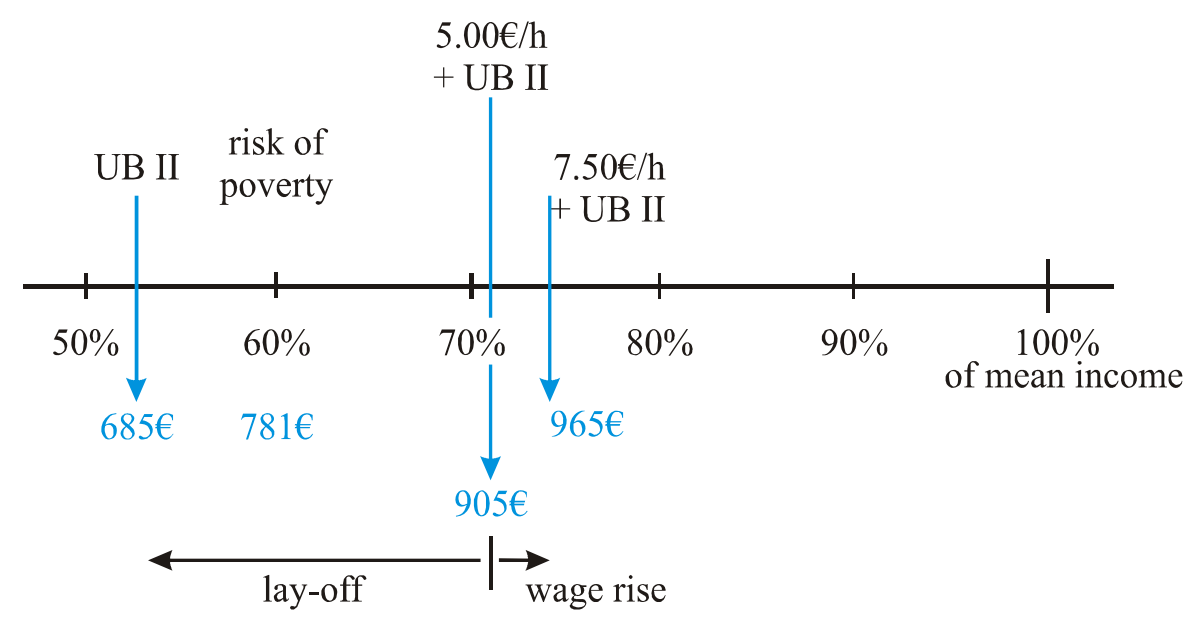

The aggregate figures presented in Table 2 confirm the reasoning of our example. Total income of all affected household rises by EUR 1.2 billion per year. The largest income gain accrues to full-time employees who receive $71 \%$ of the additional household income. Lowwage employees who receive supplementary UB II hardly benefit at all. Those who remain in employment enjoy a wage increase that is, however, very low because of the high transfer reduction rates. Those who lose their jobs will face a significantly higher loss in income. The small income gains for those who remain in employment are outweighed by the income losses of those who are laid off. In our above-mentioned example, a rise from an hourly wage of EUR 5.00 to a minimum wage of EUR 7.50 would cost 26 out of 100 employees their jobs (at the assumed labor demand elasticity of -0.75). Their net income would fall from initially EUR 925 to the basic income level of EUR 685. The remaining 74 employees each have an additional income of EUR 40. The total available income of all 100 employees eligible to UB II falls by 3.5 percent. As Figure 7 and the right column in Table 2 clearly indicate, a statutory minimum wage puts almost 170,000 employees with supplementary UB II benefits plus their family members into the risk of poverty, but fails to lift anyone in need out of it.

There are several effects on the government budget. On the one hand, increasing wage income raises taxes and social security contributions. Furthermore, as far as affected 
employees are entitled to supplementary UB II payments, these payments will be reduced. These two effects increase fiscal revenues. On the other hand, the layoffs will lower tax revenues and social security contributions and will raise expenditures on unemployment benefit.7 Summing up all effects, a statutory minimum wage of EUR 7.50 would increase the public deficit by more than EUR 4 billion per year. Thus, the statutory minimum wage also fails on this account: rather than alleviating the fiscal burden the minimum wage raises public debt.

\section{Neutralizing the minimum wage: learning from the neighbors?}

Despite the disillusioning results presented in the last section, one may nevertheless argue that the minimum wage can serve as a redistributive tool if one could only avoid the negative employment effects. The French approach of combining a minimum wage with a wage subsidy may offer a solution. The French statutory minimum wage SMIC (Salaire Minimum Interprofessionnel de croissance) has a very strong effect on the labor costs of persons with low-skilled qualifications. This is reinforced by the high social security contribution rates of $40 \%$ of the gross wage that the employers have to pay. To neutralize this effect at least partially, a subsidy of the employers' social security contributions was introduced in 1993. Since January 2005, the subsidy is $26 \%$ at the minimum wage and is then phased out linearly to the 1.6 -fold of the minimum wage. ${ }^{8}$ The wage subsidy (partly) compensates the firms for increases in the minimum wage.

An interesting feature of the French approach is that it entails an automatism that might even reduce firm's labor costs if the statutory minimum wage is raised over time. Figure 8 shows the change in labor cost when the statutory minimum wage is raised by $10 \%$. Of course, labor costs for employees who have received exactly the minimum wage increase. Since the wage interval in which the subsidy is paid is shifted upwards, however, also higherpaying jobs become subject to subsidization. For wage levels between the former and the new minimum wage, the wages to be paid rise, but the subsidy to the employer rises, too. For wages above the new minimum wage, the only effect at work is the increase in the wage

\footnotetext{
${ }^{7}$ For our calculations, we assume that all full-time and part-time employees who are laid off will receive UB I. If they received supplementary UB II even before becoming unemployed, they will receive the full UB II amount without any deductions. Persons formerly employed in a minijob who received supplementary UB II will continue to receive UB II; all other workers will not receive any public transfers when becoming unemployed. Other factor incomes are taxed at an average tax rate of $30 \%$.

${ }^{8}$ For further details, see Sterdyniak (2007).
} 
subsidy that is due to the shift of the subsidy range. In sum, the labor costs for wages between $110 \%$ and $160 \%$ of the initial minimum wage decrease by around $5 \%$ to $6 \%$. Wages between 160 and 176 per cent of the initial minimum wage now enter the subsidy zone, so that labor costs decrease in this range, too. The effect of the minimum wage on total labor cost are thus inconclusive.

Figure 8: Effects of a $10 \%$ increase in the minimum wage in France

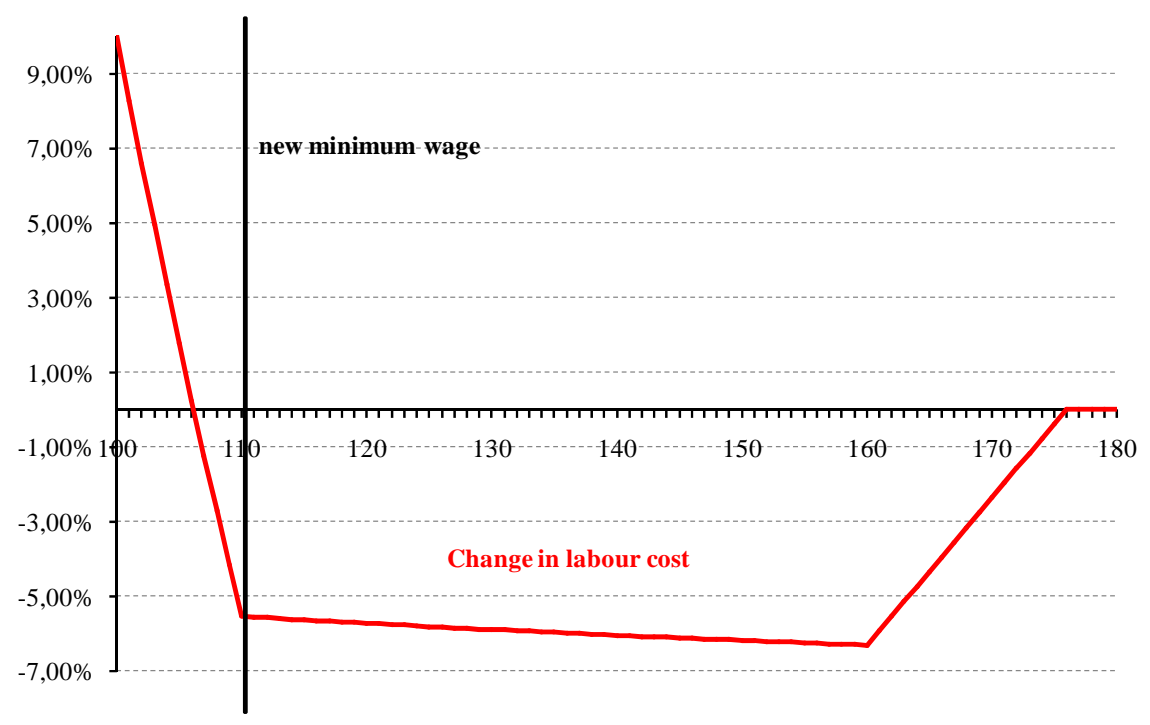

Source: Sterdyniak (2007) and own calculations.

Laroque and Salanié (2000) examined the interaction of an increase in the minimum wage and the wage subsidy to employers for the year 1997 with regulations being slightly different from today's regulations. According to their simulations, a minimum wage increase of $10 \%$ costs 290,000 jobs on a long-term basis. An extension of the subsidies, however, would create around 500,000 new jobs in return. These numbers are by all means in accordance with the results of studies stating an especially strong negative employment effect of the minimum wage among young workers without training (see Laroque and Salaniè 2002).

We simulate how an adoption of the French approach would affect the impact of minimum wages in Germany. We endogenously determine the subsidy rate that completely neutralizes the minimum wage's adverse employment effects. The wage subsidy is highest at the minimum wage level and is then linearly decreased until it fades out at $150 \%$ of the minimum wage. The endogenously determined maximum subsidy is 18.5 \% (EUR 1.39 per hour). The subsidy phases out at a wage of EUR 11.25. 
The cost of neutralizing the adverse employment effects of a minimum wage are immense. For a statutory minimum wage of EUR 7.50, the fiscal cost of the combined scheme adds up to EUR 15.6 billion per year, exceeding the fiscal cost of a pure minimum wage scheme by EUR 11.5 billion per year. Of course, the effect on household incomes is much stronger. Aggregate incomes of all households affected rise by EUR 4 billion per year compared to a pure minimum wage regime, which implies that the neutralizing scheme costs the government almost EUR 3 per Euro additional household income. This clearly indicates the inefficiency of a combined introduction of a high statutory minimum wage with neutralizing wage subsidies. The French model is - if at all - only suitable for moderate statutory minimum wages. ${ }^{9}$ But even a moderate statutory minimum wage, accompanied by a wage subsidy, could open Pandora's box. Once introduced, there would be nothing that prevents politicians from demanding ever higher minimum wage levels (see Franz et al., 2008).

Table 3 shows how the combined measure affects households with an initial hourly wage below and above the statutory minimum wage. As expected, the wage subsidy can only partly revert the increase in labor cost below EUR 7.50 but it actually lowers labor cost in the range from EUR 7.50 to EUR 11.25 (cf. Figure 5). In total, the number of jobs falls by almost 3,000 because, by keeping the number of full-time equivalent jobs constant, more minijobs are lost than full-time jobs are created. The group of persons working in a minijob is the group that loses most jobs.

Table 3: Employment effects among different target groups

\begin{tabular}{|c|c|c|c|c|c|}
\hline Initial wage & $\begin{array}{c}\begin{array}{c}\text { All } \\
\text { employees }\end{array} \\
\text { UB II }\end{array}$ & $\begin{array}{r}\begin{array}{c}\text { Full-time } \\
\text { employees }\end{array} \\
\text { UB II }\end{array}$ & $\begin{array}{r}\text { Part-time } \\
\text { employees } \\
\text { UB II }\end{array}$ & $\begin{array}{l}\text { Minijobs } \\
\text { UB II }\end{array}$ & $\begin{array}{l}\text { Pensioners \& } \\
\text { students }\end{array}$ \\
\hline$<$ EUR 7.50 & $\begin{array}{r}-398,615 \\
-94,907\end{array}$ & $\begin{array}{r}-33,470 \\
-2,708\end{array}$ & -319 & $\begin{array}{r}-320,178 \\
-91,880\end{array}$ & $-49,035$ \\
\hline >EUR 7.50 & $\begin{array}{r}395,810 \\
16,616 \\
\end{array}$ & $\begin{array}{r}203,703 \\
7,939 \\
\end{array}$ & $\begin{array}{r}54,143 \\
4,465 \\
\end{array}$ & $\begin{array}{r}103,862 \\
4,213 \\
\end{array}$ & 34,103 \\
\hline & $\begin{array}{r}-2,805 \\
-78,291\end{array}$ & \begin{tabular}{|r|}
170,233 \\
5,230
\end{tabular} & \begin{tabular}{|r|}
58,211 \\
4,146
\end{tabular} & \begin{tabular}{|r|}
$-216,316$ \\
$-87,667$
\end{tabular} & $-14,933$ \\
\hline
\end{tabular}

Source: own calculations.

\footnotetext{
${ }^{9}$ At a statutory minimum wage of EUR 5.00, the fiscal cost of the combined scheme would be EUR 2.5 billion per year compared to EUR 0.9 billion a year for a pure minimum wage scheme.
} 
The reform slightly raises the number of full-time and part-time employees who are eligible for supplementary UB II. However, UB II recipients who have a low-paid minijob are the ones who suffer most from the reform. In total, more than 78,000 UB II recipients lose their jobs and thus their supplementary wage income that keeps them above the risk-of-poverty threshold. By contrast, 75,000 additional jobs are created for those who are not in need. The resulting income effects for the different groups are shown in Table 4.

Table 4: Income effects among different target groups (in mill. Euro per year)

\begin{tabular}{|c|c|c|c|c|c|}
\hline Initial wage & $\begin{array}{c}\begin{array}{c}\text { All } \\
\text { employees }\end{array} \\
\text { UB II }\end{array}$ & $\begin{array}{r}\text { Full-time } \\
\text { empoyees } \\
\text { UB II }\end{array}$ & $\begin{array}{r}\text { Part-time } \\
\text { employees } \\
\text { UB II }\end{array}$ & $\begin{array}{l}\text { Minijobs } \\
\text { UB II }\end{array}$ & $\begin{array}{c}\text { Pensioners \& } \\
\text { students }\end{array}$ \\
\hline$<$ EUR 7.50 & -885 & -27 & -3 & -855 & 299 \\
\hline >EUR 7.50 & 1,800 & 1,051 & 47 & 433 & 128 \\
\hline Total effect & $\begin{array}{rr}5,068 & \\
& -700\end{array}$ & 2,538 & 44 & $\begin{array}{ll}1,639 & \\
& -816\end{array}$ & 427 \\
\hline
\end{tabular}

Source: own calculations.

Half of the aggregate income gain of EUR 5 billion per year accrues to full-time employees, the second largest share goes to persons with a minijob. Since the existing rules about supplementary UB II ensure that the potential gain from a minimum wage for UB II recipients is small while the income loss when laid off is much higher, full-time and part-time employees eligible for supplementary UB II hardly gain from this reform option. The only significant income effect is that less productive workers lose while those with higher productivity, ensuring a wage above the minimum wage, will benefit. UB II recipients who hold a low-paid minijob are the great losers with an annual loss of more than EUR 800 million. In total, the incomes of UB II recipients would fall so that even a minimum wage with accompanying employment-neutralizing measures fails to increase the income of the most important target group, i.e. the households in need. A neutralized minimum wage is thus not only extremely costly, it also does not raise the income of needy households.

\section{Subsidizing low wages instead, or: going beyond Agenda 2010}

Can the government do better? Why not apply a wage subsidy only? To analyze this alternative, we consider a similar wage subsidy as in the previous section: up to a certain 
wage rate, employers are fully exempted from social security contributions. This is equivalent to a $16.3 \%$ subsidy on labor cost. Up to $150 \%$ of the exemption limit, the employer contribution rates are then linearly increased until they reach the regular level of $19.5 \%$ of the gross wage. We determine the exemption limit endogenously so that the subsidy scheme costs as much as the minimum wage, i.e. EUR 4 billion per year.

If the whole incidence of the subsidy falls on the employer, the cost-equivalent exemption limit is EUR 6.83. The positive employment effects are substantial. Total employment would rise by approximately $2.5 \%$ of the total workforce or 800.000 workers. Aggregate household income is EUR 2.8 billion per year higher than in the minimum wage regime. The more the incidence falls on employees, the smaller is the employment effect because the wage subsidy has a lower impact on labor cost. Aggregate additional household income is almost stable at about EUR 4 billion per year, see Figure 9. However, the distribution of the income gains changes.

Figure 9: Employment and income depending on subsidy incidence

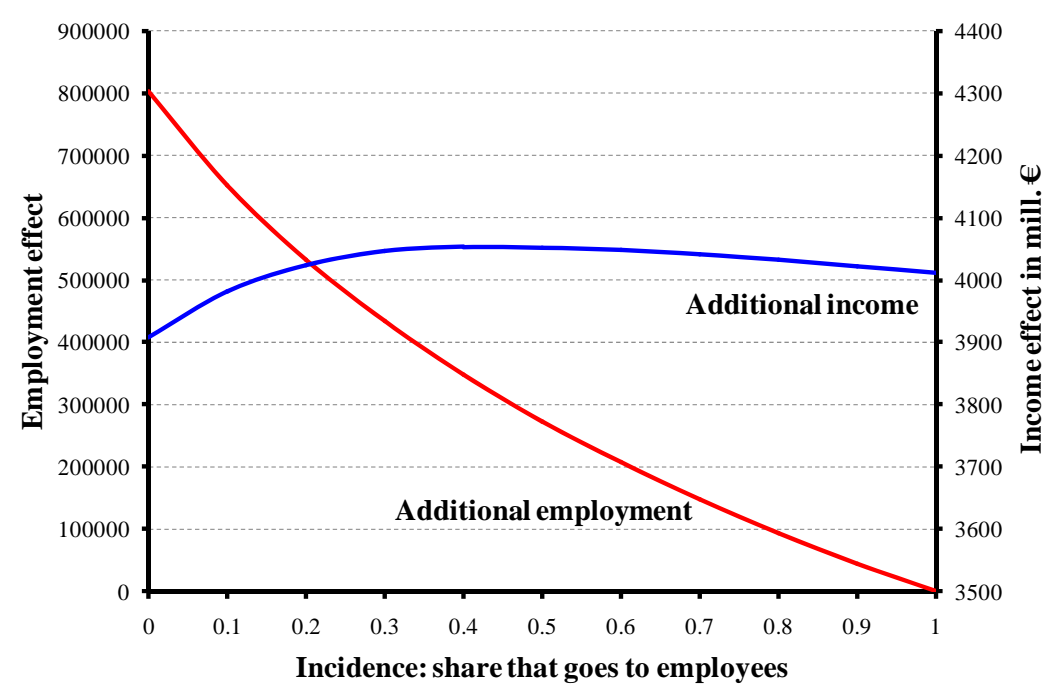

Source: own calculations

If the incidence falls entirely on employers, incomes of incumbent workers do not change, but some formerly unemployed persons get a job. Since wages in the low-wage sector hardly exceed the level of unemployment benefits of short-term unemployed or, in the case of UB II recipients, are subject to high transfer-reduction rates, the incomes of the new employees eligible to UB II do not rise very much. If the subsidy on social security contributions is fully shifted to employees, the cost-equivalent exemption limit would be EUR 5.65. In this case, 
employment stays constant, but incumbent employees benefit from a substantial net wage raise.

\section{Which way to go?}

Table 5 summarizes the main results of our simulations and shows that the pure wage subsidy, irrespective of the final incidence of the subsidy scheme, is superior to a statutory minimum wage: at the same fiscal cost, both employment and income effects are more favorable. The French approach provides slightly higher household incomes, but comes at a huge fiscal cost.

Table 5: Summary: changes relative to status quo

\begin{tabular}{l|cc}
\hline \hline & $\begin{array}{c}\text { Additional } \\
\text { Change in } \\
\text { employment } \\
\text { incomehold } \\
\text { mill. EUR } \\
\text { p.a. }\end{array}$ \\
\hline $\begin{array}{l}\text { minimum wage of EUR 7.50 } \\
\text { pure wage subsidy (incidence on } \\
\text { employers) }\end{array}$ & $+842,033$ & $+1,156$ \\
$\begin{array}{l}\text { pure wage subsidy (incidence on } \\
\text { employees) }\end{array}$ & 0 & $+3,908$ \\
$\begin{array}{l}\text { minimum wage of EUR 7.50 } \\
\text { plus linear wage subsidy } \\
\text { (incidence on employers) }\end{array}$ & $-2,805$ & $+4,011$ \\
\hline \hline
\end{tabular}

Source: own calculations.

These figures suggest to reconsider proposals that aim at going beyond the reforms of the Agenda 2010. These proposals favor a combined wage (Kombilohn): the wage bill is partly paid by the firm and partly by the government. These proposals can be separated into schemes similar to the US Earned Income Tax Credit program that subsidizes employees and schemes that aim to subsidize employers directly.

The most prominent proposal of the former type is called Activating Welfare (Aktivierende Sozialhilfe), developed by the ifo-Institute (see Sinn et al. 2006, 2007). According to this proposal, the government should provide supplementary benefits to an extent that the first EUR 500 of the wage income are no longer deducted from the public transfers. In addition, a wage subsidy of $20 \%$ of the first EUR 200 of the income is granted. In return, the UB II is reduced by EUR 351 (only accommodation costs are provided). For 
low wages, both income and substitution effects would have a strong positive effect on labor supply and would thus increase wage pressure. For wages above EUR 500, the benefitreduction rate is significantly decreased and amounts to approximately 71 per cent - in contrast to 80 to 100 per cent according to the current regulations. In Figure 10, the black line shows the net income a single person household receives depending on his gross earnings (without employer's social security contributions) according to Activating Welfare.

Figure 10: Subsidizing employees

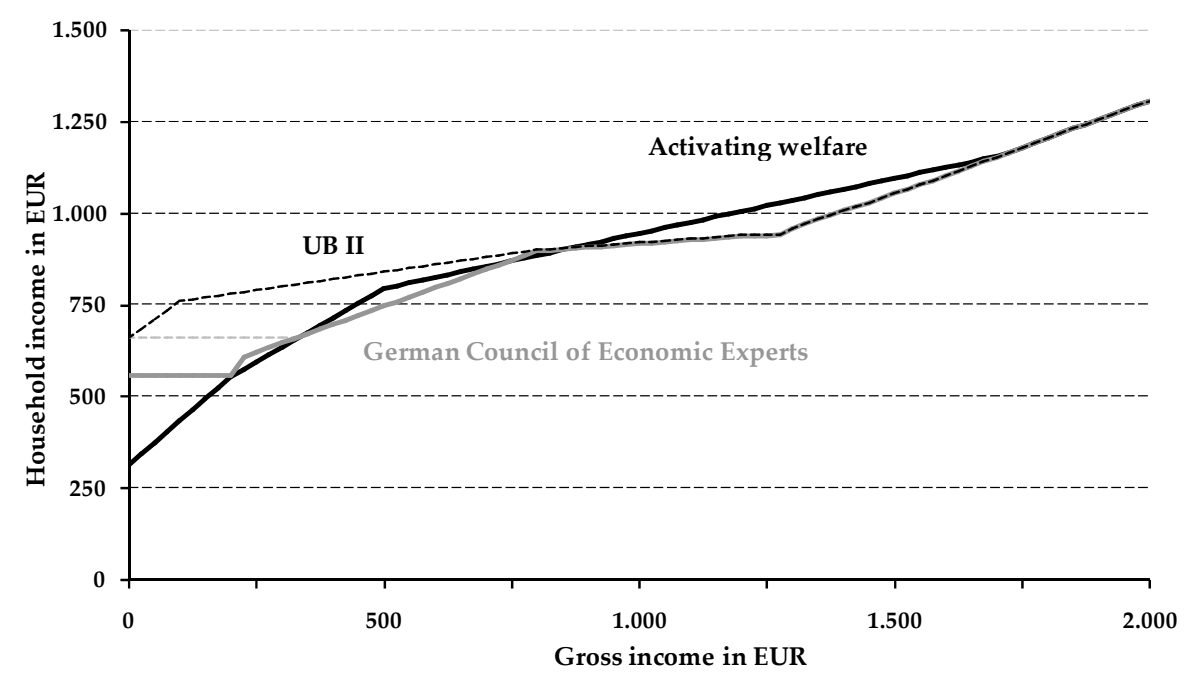

Legend: For the calculation of the housing costs, a rent of 7 Euros ( including heating) per square meter is assumed. Further explanations are given in the text.

Since the reduction of UB II would result in an income below the level of the basic income, each UB II recipient can secure a minimum income according to the current UB II regulations by working with a municipal employment society, a public works institution, or with a municipal temporary employment agency. The wage subsidy is thus accompanied by workfare elements that create strong incentives for those taking up a publicly subsidized job to look for better paid employment on the regular labor market.

The proposal of the German Council of Economic Experts (see Sachverständigenrat zur Begutachtung der gesamtwirtschaftlichen Entwicklung 2006a, b) is very similar in vein but puts a stronger focus on making low-paid full-time jobs more attractive. For this reason, the Council suggests to completely deduct the first EUR 200 of the gross income from UB II payments. In return, the possibilities to earn a supplementary income above the level of EUR 
200 are improved. For wages above EUR 200, the first EUR 40 are exempted from any deductions to cover income-related expenses. Additional income is subject to a transferreduction rate of $50 \%$ up to EUR 800. Above EUR 800, the transfer-reduction rates are the same as in the current system. Like the ifo-Institute, the German Council of Economic Experts also proposes a reduction of the current UB II, but at a smaller amount of only EUR 100, and suggests additional workfare measures. The grey line in Figure 10 shows the resulting net income for a single person household. Both proposals aim at reforming the existing systems by further improving in-work-benefits and adding workfare elements.

An alternative proposal suggests to directly subsidize labor costs. The Magdeburg Alternative (Schöb and Weimann 2006, and Knabe, Schöb, and Weimann 2006) suggests a permanent rebate of social security contributions for employers. In this respect, this proposal is close to the proposal discussed above. An employer who hires a UB II recipient with a wage below a maximum support limit is refunded the complete amount of the social security contributions, i.e. employee's and employer's contributions. For a gross income of EUR 1,000 per month, this is a refund of approx. EUR 400.

Basically, the Magdeburg Alternative proposes a target group-related subsidy and thus faces the risk that the scheme crowds out regularly employed and paid workers without creating new jobs. To avoid such a "revolving door effect", the subsidy is granted only for extra jobs within firms. Furthermore, to avoid the outsourcing of simple work to new firms and cheap wage competitors, existing firms receive not only a rebate of the social security contributions for a newly hired worker, but also for an already employed one. This "double subsidization" creates strong incentives for incumbent firms not to outsource low-paid work (see Knabe, Schöb and Weimann 2006, and Knabe and Schöb 2007 for a formal analysis). Like the other wage subsidy proposals, the Magdeburg Alternative also suggests workfare elements to ensure that the stimulated labor demand meets sufficient labor supply. While the long-run impact of all these proposals is rather similar, the difference lies in their timing. The proponents of the Magdeburg Alternative favor wage subsidies to employers because they reduce wage cost immediately without having to wait until wage subsidies given to employees are transformed into lower gross wages.

When the new German government after the 2009 election has to decide which way to go, it should be aware that, whichever of these wage subsidy proposals one prefers, the results in Table 5 clarify that all of them - being allocatively rather similar in the long-run - are 
superior to a minimum wage. If the government introduced a minimum wage, it would reduce employment opportunities for the low-skilled and raise public expenditures on unemployment and welfare benefits. If the government is willing to spend the same amount of money directly on wage subsidies, it could achieve more favorable employment and income effects than with minimum wages. If it uses the subsidy to neutralize the adverse effects of a minimum wage, the government would forgo employment opportunities and only realize small income gains at huge fiscal cost. Hence, the government should keep its hands off minimum wages altogether and proceed further on the route taken by Agenda 2010: the more efficient way for the welfare state to fulfill its responsibility of ensuring sufficient incomes and employment prospects for those in need is to implement policies to subsidize low-paid jobs directly.

\section{References}

Acemoglu, D. (2002): “Technical Change, Inequality and the Labor Market”, Journal of Economic Literature 40, 7-72.

Acemoglu, D. (2003): “Cross-Country Inequality Trends”, Economic Journal 113, F121F149.

Bundesministerium für Arbeit und Soziales (2008a): Lebenslagen in Deutschland. der 3. Armuts- und Reichtumsbericht der Bundesregierung, Entwurf vom 19. Mai 2008, Berlin.

Bundesministerium für Arbeit und Soziales (2008b): Die 10 wichtigsten Fragen und Antworten zum Mindestlohn, http://194.145.122.101/sites/generator/25932/property=pdf/faq.pdf

Brenke, K., and K. Zimmermann (2008): "Reformagenda 2010 - Strukturreformen für Wachstum und Beschäftigung“, DIW Wochenbericht Nr. 11/2008, 117-124.

Dustmann, C., J. Lundstek,, and U. Schönberg (2008): "Revisiting the German Wage Structure”, forthcoming in Quarterly Journal of Economics.

de Mooj, R. (2006): Reinventing the welfare state, CPB Netherlands Bureau for Economic Policy Analysis: The Hague.

Eurostat (2008): Minimum Wages, http://epp.eurostat.ec.europa.eu/portal/page? pageid=1996,45323734\&_dad=portal\&_schema=PORTAL\&screen=welcomeref\&open=/l abour/earn/earn_minw\&language=de\&product=EU_MASTER_labour_market\&root=EU_ MASTER_labour_market\&scrollto=0

Franz, W. (2007): "Ein zielgerichtetes Kombilohnmodell: Der Vorschlag des Sachverständigenrates“, ifo Schnelldienst 60 (4), 24-28.

Gernandt, J., and F. Pfeiffer (2007): "Rising Wage Inequality in Germany”, Jahrbücher für Nationalökonomie und Statistik 227(4), 358-380.

Hans-Böcker-Stiftung (2008): WSI Mindestlohndatenbank 2008, http://www.boecklerboxen.de/4663.htm

Knabe, A. und S. Rätzel (2007): Quantifying the psychological costs of unemployment: the role of permanent income, FEMM Working Paper No. 12/2007, Otto-von-Guericke University Magdeburg.

Knabe, A. and R. Schöb (2007): Subsidizing Extra Jobs: Promoting Employment by Taming the Unions, CESifo Working Paper No. 2130, October.

Knabe, A. and R. Schöb (2008): Minimum wage incidence: the case for Germany, CESifo Working Paper No. 2432, October

Knabe, A., R. Schöb und J. Weimann (2006): "Marginal Employment Subsidization: A New Concept and a Reappraisal”, Kyklos 50(4), 557-578.

Kramarz F. und T. Philippon (2001): "The Impact of Differential Payroll Tax Subsidies on Minimum Wage Employment”, Journal of Public Economics, 82, 115-146. 
Laroque, G. und B. Salanié (2002): “Une Décomposition du Non-Emploi en France”, Economie et Statistique Nr. 331, 47-66.

Laroque, G. und B. Salanié (2002): "Labour Market Institutions and Employment in France”, Journal of Applied Econometrics 17, 25 - 48.

Marx, I. (2001): "Job subsidies and cuts in employers' social security contributions: The verdict of empirical evaluation studies”, International Labour Review 140 (1), 69-85.

Mühlau, P., and W. Salverda (2000): "Employment and Earnings Effects of Low-Wage Subsidies: The Case of SPAK in the Netherlands", in W. Salverda, C. Lucifora, and B. Nolan (eds.), Policy Measures for Low-Wage Employment in Europe, Cheltenham.

OECD (2008): Employment Outlook. Statistical Annex, OECD: Paris.

Prasad, E. (2004): "The unbearable stability of the German wage structure: evidence and interpretation”, IMF Staff Papers 51(2), 354-385.

Ragnitz, J. and M. Thum (2007): "The empirical relevance of minimum wages for the lowwage sector in Germany”, CESifo Forum 2/2007, 35-37.

Sachverständigenrat zur Begutachtung der gesamtwirtschaftlichen Entwicklung (2002): Zwanzig Punkte für Beschäftigung und Wachstum, Jahresgutachten 2002/2003, Stuttgart: Metzler-Poeschler.

Sachverständigenrat zur Begutachtung der gesamtwirtschaftlichen Entwicklung (2006): Widerstreitende Interessen - Ungenutzte Chancen, Jahresgutachten 2006/2007, Stuttgart: Metzler-Poeschler.

Schnabel, C., and J. Wagner (2008): The Aging of the Unions in West Germany, 1980-2006, IZA Discussion Paper No. 3661, Bonn.

Schöb R. und J. Weimann (2006): Arbeit ist machbar - Die Magdeburger Alternative: Eine sanfte Therapie für Deutschland, Janos Stekovics Verlag: Dößel, 5. Auflage.

Sinn, H.-W. et al. (2006): Redesigning the Welfare State. Germany's Current Agenda for an Activating Social Assistance, Edward Elgar: Cheltenham.

Sinn, H.-W. et al. (2007): „Die zentralen Elemente der Aktivierenden Sozialhilfe“, ifo Schnelldienst 60 (4), 48-53.

Statistisches Bundesamt (2008): Statistical Yearbook 2008 for the Federal Republic of Germany, Statistisches Bundesamt: Wiesbaden.

Statistik der Bundesagentur für Arbeit (2007): Grundsicherung für Arbeitssuchende: Anrechenbare Einkommen und Erwerbsfähigkeit, Nürnberg im August 2007.

Sterdyniak, H. (2007): "Low-skilled Jobs: The French Strategy", Documents de Travail de l'OFCE 2007-15, Observatoire Francais des Conjonctures Economiques (OFCE).

Wagner, G., J. Frick, and J. Schupp (2007): "The German Socio-Economic Panel Study (SOEP) - Scope Evolution and Enhancements”, Schmollers Jahrbuch 127(1), 139-169. 


\section{CESifo Working Paper Series}

for full list see www.cesifo-group.org/wp

(address: Poschingerstr. 5, 81679 Munich, Germany, office@cesifo.de)

2433 Kurt R. Brekke and Odd Rune Straume, Pharmaceutical Patents: Incentives for R\&D or Marketing?, October 2008

2434 Scott Alan Carson, Geography, Insolation, and Institutional Change in $19^{\text {th }}$ Century African-American and White Stature in Southern States, October 2008

2435 Emilia Del Bono and Daniela Vuri, Job Mobility and the Gender Wage Gap in Italy, October 2008

2436 Marco Angrisani, Antonio Guarino, Steffen Huck and Nathan Larson, No-Trade in the Laboratory, October 2008

2437 Josse Delfgaauw and Robert Dur, Managerial Talent, Motivation, and Self-Selection into Public Management, October 2008

2438 Christian Bauer and Wolfgang Buchholz, How Changing Prudence and Risk Aversion Affect Optimal Saving, October 2008

2439 Erich Battistin, Clara Graziano and Bruno Parigi, Connections and Performance in Bankers' Turnover: Better Wed over the Mixen than over the Moor, October 2008

2440 Erkki Koskela and Panu Poutvaara, Flexible Outsourcing and the Impacts of Labour Taxation in European Welfare States, October 2008

2441 Marcelo Resende, Concentration and Market Size: Lower Bound Estimates for the Brazilian Industry, October 2008

2442 Giandomenico Piluso and Roberto Ricciuti, Fiscal Policy and the Banking System in Italy. Have Taxes, Public Spending and Banks been Procyclical in the Long-Run? October 2008

2443 Bruno S. Frey and Katja Rost, Do Rankings Reflect Research Quality?, October 2008

2444 Guglielmo Maria Caporale, Antoaneta Serguieva and Hao Wu, Financial Contagion: Evolutionary Optimisation of a Multinational Agent-Based Model, October 2008

2445 Valentina Bosetti, Carlo Carraro and Massimo Tavoni, Delayed Participation of Developing Countries to Climate Agreements: Should Action in the EU and US be Postponed?, October 2008

2446 Alexander Kovalenkov and Xavier Vives, Competitive Rational Expectations Equilibria without Apology, November 2008

2447 Thiess Buettner and Fédéric Holm-Hadulla, Cities in Fiscal Equalization, November 2008 
2448 Harry H. Kelejian and Ingmar R. Prucha, Specification and Estimation of Spatial Autoregressive Models with Autoregressive and Heteroskedastic Disturbances, November 2008

2449 Jan Bouckaert, Hans Degryse and Thomas Provoost, Enhancing Market Power by Reducing Switching Costs, November 2008

2450 Frank Heinemann, Escaping from a Combination of Liquidity Trap and Credit Crunch, November 2008

2451 Dan Anderberg, Optimal Policy and the Risk Properties of Human Capital Reconsidered, November 2008

2452 Christian Keuschnigg and Evelyn Ribi, Outsourcing, Unemployment and Welfare Policy, November 2008

2453 Bernd Theilen, Market Competition and Lower Tier Incentives, November 2008

2454 Ondřej Schneider, Voting in the European Union - Central Europe's Lost Voice, November 2008

2455 Oliver Lorz and Gerald Willmann, Enlargement versus Deepening: The Trade-off Facing Economic Unions, November 2008

2456 Alfons J. Weichenrieder and Helen Windischbauer, Thin-Capitalization Rules and Company Responses, Experience from German Legislation, November 2008

2457 Andreas Knabe and Steffen Rätzel, Scarring or Scaring? The Psychological Impact of Past Unemployment and Future Unemployment Risk, November 2008

2458 John Whalley and Sean Walsh, Bringing the Copenhagen Global Climate Change Negotiations to Conclusion, November 2008

2459 Daniel Mejía, The War on Illegal Drugs in Producer and Consumer Countries: A Simple Analytical Framework, November 2008

2460 Carola Frydman, Learning from the Past: Trends in Executive Compensation over the Twentieth Century, November 2008

2461 Wolfgang Ochel, The Political Economy of Two-tier Reforms of Employment Protection in Europe, November 2008

2462 Peter Egger and Doina Maria Radulescu, The Influence of Labor Taxes on the Migration of Skilled Workers, November 2008

2463 Oliver Falck, Stephan Heblich and Stefan Kipar, The Extension of Clusters: Differencein-Differences Evidence from the Bavarian State-Wide Cluster Policy, November 2008

2464 Lei Yang and Keith E. Maskus, Intellectual Property Rights, Technology Transfer and Exports in Developing Countries, November 2008 
2465 Claudia M. Buch, The Great Risk Shift? Income Volatility in an International Perspective, November 2008

2466 Walter H. Fisher and Ben J. Heijdra, Growth and the Ageing Joneses, November 2008

2467 Louis Eeckhoudt, Harris Schlesinger and Ilia Tsetlin, Apportioning of Risks via Stochastic Dominance, November 2008

2468 Elin Halvorsen and Thor O. Thoresen, Parents' Desire to Make Equal Inter Vivos Transfers, November 2008

2469 Anna Montén and Marcel Thum, Ageing Municipalities, Gerontocracy and Fiscal Competition, November 2008

2470 Volker Meier and Matthias Wrede, Reducing the Excess Burden of Subsidizing the Stork: Joint Taxation, Individual Taxation, and Family Splitting, November 2008

2471 Gunther Schnabl and Christina Ziegler, Exchange Rate Regime and Wage Determination in Central and Eastern Europe, November 2008

2472 Kjell Erik Lommerud and Odd Rune Straume, Employment Protection versus Flexicurity: On Technology Adoption in Unionised Firms, November 2008

2473 Lukas Menkhoff, High-Frequency Analysis of Foreign Exchange Interventions: What do we learn?, November 2008

2474 Steven Poelhekke and Frederick van der Ploeg, Growth, Foreign Direct Investment and Urban Concentrations: Unbundling Spatial Lags, November 2008

2475 Helge Berger and Volker Nitsch, Gotcha! A Profile of Smuggling in International Trade, November 2008

2476 Robert Dur and Joeri Sol, Social Interaction, Co-Worker Altruism, and Incentives, November 2008

2477 Gaëtan Nicodème, Corporate Income Tax and Economic Distortions, November 2008

2478 Martin Jacob, Rainer Niemann and Martin Weiss, The Rich Demystified - A Reply to Bach, Corneo, and Steiner (2008), November 2008

2479 Scott Alan Carson, Demographic, Residential, and Socioeconomic Effects on the Distribution of $19^{\text {th }}$ Century African-American Stature, November 2008

2480 Burkhard Heer and Andreas Irmen, Population, Pensions, and Endogenous Economic Growth, November 2008

2481 Thomas Aronsson and Erkki Koskela, Optimal Redistributive Taxation and Provision of Public Input Goods in an Economy with Outsourcing and Unemployment, December 2008 
2482 Stanley L. Winer, George Tridimas and Walter Hettich, Social Welfare and Coercion in Public Finance, December 2008

2483 Bruno S. Frey and Benno Torgler, Politicians: Be Killed or Survive, December 2008

2484 Thiess Buettner, Nadine Riedel and Marco Runkel, Strategic Consolidation under Formula Apportionment, December 2008

2485 Irani Arraiz, David M. Drukker, Harry H. Kelejian and Ingmar R. Prucha, A Spatial Cliff-Ord-type Model with Heteroskedastic Innovations: Small and Large Sample Results, December 2008

2486 Oliver Falck, Michael Fritsch and Stephan Heblich, The Apple doesn't Fall far from the Tree: Location of Start-Ups Relative to Incumbents, December 2008

2487 Cary Deck and Harris Schlesinger, Exploring Higher-Order Risk Effects, December 2008

2488 Michael Kaganovich and Volker Meier, Social Security Systems, Human Capital, and Growth in a Small Open Economy, December 2008

2489 Mikael Elinder, Henrik Jordahl and Panu Poutvaara, Selfish and Prospective: Theory and Evidence of Pocketbook Voting, December 2008

2490 Maarten Bosker and Harry Garretsen, Economic Geography and Economic Development in Sub-Saharan Africa, December 2008

2491 Urs Fischbacher and Simon Gächter, Social Preferences, Beliefs, and the Dynamics of Free Riding in Public Good Experiments, December 2008

2492 Michael Hoel, Bush Meets Hotelling: Effects of Improved Renewable Energy Technology on Greenhouse Gas Emissions, December 2008

2493 Christian Bruns and Oliver Himmler, It's the Media, Stupid - How Media Activity Shapes Public Spending, December 2008

2494 Andreas Knabe and Ronnie Schöb, Minimum Wages and their Alternatives: A Critical Assessment, December 2008 